\title{
Correction to: Explainable artificial intelligence (XAI) interactively working with humans as a junior cyber analyst
}

\author{
Eric Holder ${ }^{1}$ (D) - Ning Wang ${ }^{2}$
}

Published online: 22 October 2021

(c) The Author(s) 2021

\section{Correction to: Human-Intelligent Systems Integration (2021) https://doi.org/10.1007/s42454-020-00021-z}

The article Explainable artificial intelligence (XAI) interactively working with humans as a junior cyber analyst, written by Eric Holder, was originally published Online First without Open Access. After publication in volume 5, issue 1, page 21-33 the author decided to opt for Open Choice and to make the article an Open Access publication. Therefore, the copyright of the article has been changed to $(\odot)$ The Author(s) 2021 and the article is forthwith distributed under the terms of the Creative Commons Attribution 4.0 International License, which permits use, sharing, adaptation, distribution and reproduction in any medium or format, as long as you give appropriate credit to the original author(s) and the source, provide a link to the Creative Commons licence, and indicate if changes were made. The images or other third party material in this article are included in the article's Creative Commons licence, unless indicated otherwise in a credit line to the material. If material is not included in the article's Creative Commons licence and your intended use is not permitted by statutory regulation or exceeds the permitted use, you will need to obtain permission directly from the copyright holder. To view a copy of this licence, visit http://creativecommons.org/licenses/by/4.0/.

Open Access funding enabled and organized by Projekt DEAL.

Publisher's note Springer Nature remains neutral with regard to jurisdictional claims in published maps and institutional affiliations.
The original article can be found online at https://doi.org/10.1007/ s42454-020-00021-z

Eric Holder

eric.w.holder4.civ@army.mil

Ning Wang

nwang@act.edu

1 DEVCOM, US Army Research Laboratory, Ft. Huachuca, AZ 85613, USA

2 Institute for Creative Technologies, University of Southern California, Marina Del Rey, CA 32826, USA 